\title{
ArcheoSciences
}

Revue d'archéométrie

$37 \mid 2013$

Varia

\section{Interdisciplinary Study of the Early Building Phases of St Irénée's Church (Lyon, France): The Contribution of Luminescence Dating}

Étude interdisciplinaire des phases de constructions primitives de l'église Saint-

Irénée (Lyon, France) : contribution de la datation par luminescence

Armel Bouvier, Pierre Guibert, Sophie Blain and Jean-François Reynaud

(2) OpenEdition

Journals

\section{Electronic version}

URL: https://journals.openedition.org/archeosciences/4053

DOI: 10.4000/archeosciences.4053

ISBN: $978-2-7535-2755-3$

ISSN: $2104-3728$

Publisher

Presses universitaires de Rennes

Printed version

Date of publication: 17 April 2013

Number of pages: $155-173$

ISBN: $978-2-7535-2757-7$

ISSN: 1960-1360

Electronic reference

Armel Bouvier, Pierre Guibert, Sophie Blain and Jean-François Reynaud, "Interdisciplinary Study of the Early Building Phases of St Irénée's Church (Lyon, France): The Contribution of Luminescence Dating", ArcheoSciences [Online], 37 | 2013, Online since 17 April 2015, connection on 28 January 2022. URL: http://journals.openedition.org/archeosciences/4053; DOI: https://doi.org/10.4000/archeosciences. 4053 


\title{
Interdisciplinary Study of the Early Building Phases of St Irénée's Church (Lyon, France): The Contribution of Luminescence Dating
}

\author{
Étude interdisciplinaire des phases de constructions primitives \\ de l'église Saint-Irénée (Lyon, France): \\ contribution de la datation par luminescence
}

\begin{abstract}
Armel Bouvier*, Pierre GuiberT**, Sophie Blain** et Jean-François Reynaud ${ }^{* * *}$
\end{abstract}

\begin{abstract}
The church of Saint-Irénée in Lyons, the capital city of the Gauls, is one of the oldest witnesses of Christianization, and it also attests to the evolution of Lyons under the aegis of the Burgundians. New archaeological and historical data and a luminescence dating campaign presented here have renewed the previously held views on the development of the church of Saint-Irénée through the first centuries of its existence. Three main building stages were detected and the two first within a very short time span. According to the new data, the first building stage would have occurred between the 5th century and the beginning of the 6th century, the second one between the beginning of the 6th century and the beginning of the 7th century and the third one could be around the 9th-10th century period. Furthermore, we noticed that reused Gallo-Roman bricks were frequently set into the masonries which were studied in conjunction with the early medieval bricks that were specially produced for the (re)building stages already mentioned, which was unexpected.
\end{abstract}

Résumé: Cette église est l'un des plus anciens témoins conservés de la christianisation de la région Lyonnaise, capitale des Gaules, et de son évolution sous l'égide des Burgondes. La reprise des travaux archéologiques combinés à une campagne de datation par luminescence présentée ici, ont permis de restituer l'évolution du bâtiment pendant les premiers siècles de son existence, en mettant en corrélation les données textuelles, les observations sur le terrain ainsi que le raisonnement archéologique et les datations obtenues. Il a ainsi pu être attesté l'existence de trois périodes de construction ou de réaménagements relativement proches dans le temps: une première phase recouvrant le v' siècle et le début du ve siècle, une deuxième entre le début du vT siècle et le début du VII siècle et enfin une troisième probable entre le IXe et le Xe siècle. On a par ailleurs remarqué une pratique fréquente du remploi en concomitance avec une production ad novo dans les maçonneries étudiées, ce qui nétait pas une évidence initiale.

Keyword: Architectural ceramic building materials, Luminescence dating, Lyons, Middle Ages.

Mots-clés: Datations par luminescence, Lyon, Moyen Âge, terres cuites architecturales.

\footnotetext{
* Institut de Recherche sur les Archéomatériaux - Centre de Recherche en Physique Appliquée à l'Archéologie, IRAMAT-CRP2A - UMR 5060, CNRS - Université de Bordeaux 3, Maison de l'Archéologie F33607 Pessac cedex. (armel.bouvier@u-bordeaux3.fr)

** Institut de Recherche sur les Archéomatériaux - Centre de Recherche en Physique Appliquée à l'Archéologie, IRAMAT-CRP2A - UMR 5060, CNRS - Université de Bordeaux 3, Maison de l'Archéologie F 33607 Pessac cedex.

*** Laboratoire Archéométrie et Archéologie - UMR 5138, CNRS, Université Lumière Lyon 2.
} 


\section{INTRODUCTION}

The study presented here takes place in the framework of the European Research Group (GdRE) "Ceramic Building Materials and New dating Methods" supported by the CNRS, bringing together specialists of building archaeology, historians, and art historians and dating specialists. This paper focuses on the luminescence dating results and their interpretation according to the building archaeology study.

\section{Chronological questions}

Saint-Irénée's church is one of the last standing buildings of early Christian Lyons, one of the centres of Christianization of the Gauls (Février et al., 1986). The church, located on the hill of Fourvière, was built on the necropolises of Lugdunum, Gallo-Roman capital of the Gauls, where many architectural remains can be found. This particular location is supposed to have influenced building methods, due to the large amount of building materials available there.

A further analysis of the walls of the church and its openings and building surveys of the lower parts of the crypt, led one of us to consider several building stages (Reynaud, 1998; Reynaud \& Puel, 2006) that are recalled herafter.

The first stage would have consisted of the walls of a large basilica and its two lateral doors whose walls in large size bond are considered as characteristic of the 5th century construction technique, but it was necessary to confirm its dating. Moreover, these walls were probably related to the semi-circular apse in large choin stone (local limestone) formerly found by A. Audin (Audin \& Perrat, 1959). The polygonal apse, the stairs, the aisled crypt-hall would have belonged to one or several later building stages. But the lack of well-dated regional comparisons prevents archaeologists from dating the early medieval use of bricks in stone masonries with certainty. In this case, the chronology of the walls with rows of bricks on the stairs leading down to the crypt and that of the stone and brick voussoirs of the apse remains uncertain. Therefore the chronology of the crypt remains floating between the 6th and the 9th century. Any of these features could have been built either at the Burgondo-Merovingian time or at the Carolingian period. A fundamental question was then addressed and only chronometric methods could help to better organise and date the archaeological data.

\section{Site sampling}

At the beginning of this study, bricks were supposed chronologically homogeneous, since the archaeological observations did not give any evidence of reuse of building material. The brick sampling was then supposed to allow building phases dating, according to a very classical and general approach. Therefore, 14 bricks were drilled from structures belonging to the identified stages (table 1).

\begin{tabular}{|c|c|c|c|}
\hline \multirow[t]{2}{*}{ Sampled structure } & \multirow{2}{*}{ Location information } & \multicolumn{2}{|c|}{ Laboratory } \\
\hline & & sample & code \\
\hline \multirow{8}{*}{ Accesses to the crypt } & \multirow{3}{*}{ median row of bricks } & BDX & 11998 \\
\hline & & BDX & 11999 \\
\hline & & BDX & 12000 \\
\hline & \multirow{2}{*}{ upper row of bricks } & BDX & 12001 \\
\hline & & BDX & 12002 \\
\hline & \multirow{3}{*}{ lower row of bricks } & BDX & 12003 \\
\hline & & BDX & 12004 \\
\hline & & BDX & 12005 \\
\hline \multirow{6}{*}{ Outside } & \multirow{3}{*}{ south-eastern window } & BDX & 12006 \\
\hline & & BDX & 12007 \\
\hline & & BDX & 12008 \\
\hline & \multirow{3}{*}{ northern lintel } & BDX & 12009 \\
\hline & & BDX & 12010 \\
\hline & & BDX & 12011 \\
\hline
\end{tabular}

Table 1: Sample location and laboratory codes.

Tableau 1: Structure d'appartenance des échantillons prélevés et leurs références au laboratoire.

Three areas were then concerned by this operation, as we can see on figure 1 .

Two series of bricks were sampled on the outside facing of the building. Three bricks from the northern lintel of the door, thought to be the earliest access to the crypt and belong to the first building stage of the crypt (figure 2). Three others were sampled in a voussoir of a window located in the south east of the crypt apse, supposed to belong to the second building stage of the crypt (figure 3 ).

The last zone is in the current stairways to the crypt (figure 4). The bricks sampled are inserted into the west wall of these accesses. Two of them belong to the upper levelling course, three to the middle one and three to the lower levelling course. This may allow us to check whether this structure was built once as a whole during the second building stage or at different stages. 


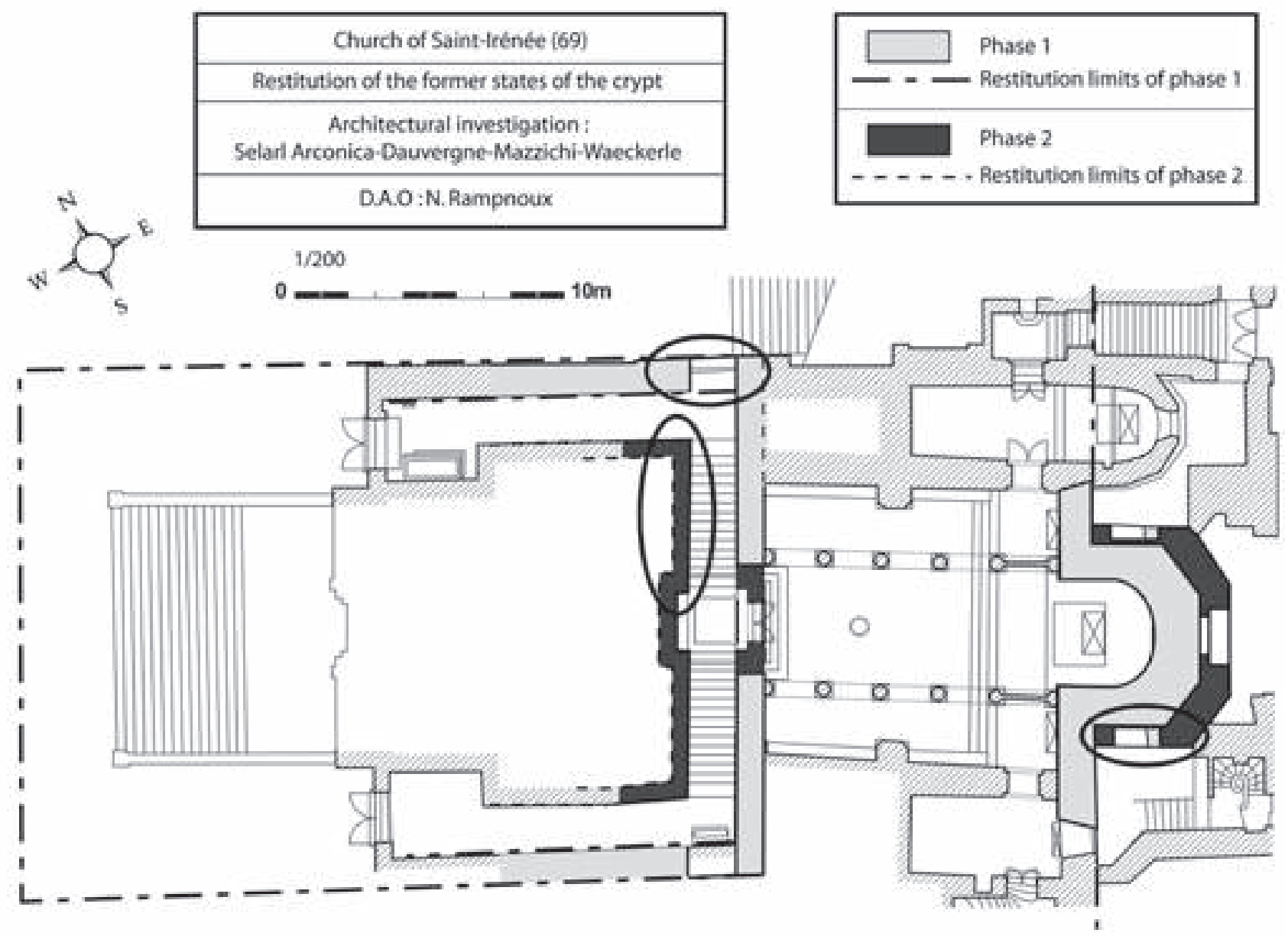

Figure 1: Plan of the current church of Saint-Irénée of Lyons.

Figure 1: Plan de l'église actuelle Saint-Irénée de Lyon.

The dotted areas are preserved remains of the first building phase. The long-stroke, dash lines are related to the hypothetical plan of the church at the first building phase. The mid-grey areas correspond to the remains identified as part of a hypothetical second phase and the dark-grey areas to a possible extension of the second phase (Reynaud \& Puel, 2006). The dash lines are hypothetical edges of the second phase. The light-grey areas are supposed to belong to the third building phase and the long stroke lines represent the hypothetical limits of the building phase. The mixed light-grey and mid-grey bands areas correspond to standing masonry structures that could belong to the second building phase for the lower parts and to the third one for the upper parts. The black circles indicate the masonry structure sampled.

Les zones pointillées correspondent aux structures préservées du premier édifice. Les lignes de tirets alternés longs et courts marquent la restitution possible de ce premier édifice. Les zones d'un gris moyen correspondent aux restes identifiés comme faisant partie d'une hypothétique deuxième phase et les zones gris foncé indiquent une éventuelle extension de la deuxième phase (Reynaud et Puel, 2006). Les lignes de tirets marquent les bords hypothétiques de la deuxième phase. Les zones gris clair sont censées appartenir à la troisième phase de construction et les lignes à longs tirets représentent les limites possibles de cette phase de construction. Les zones mélangeant gris moyen et gris clair correspondent à des structures de maçonnerie qui pourraient appartenir à la deuxième phase de construction pour les parties basses et à la troisième pour les parties hautes. Les cercles noirs indiquent les maçonneries échantillonnées. 

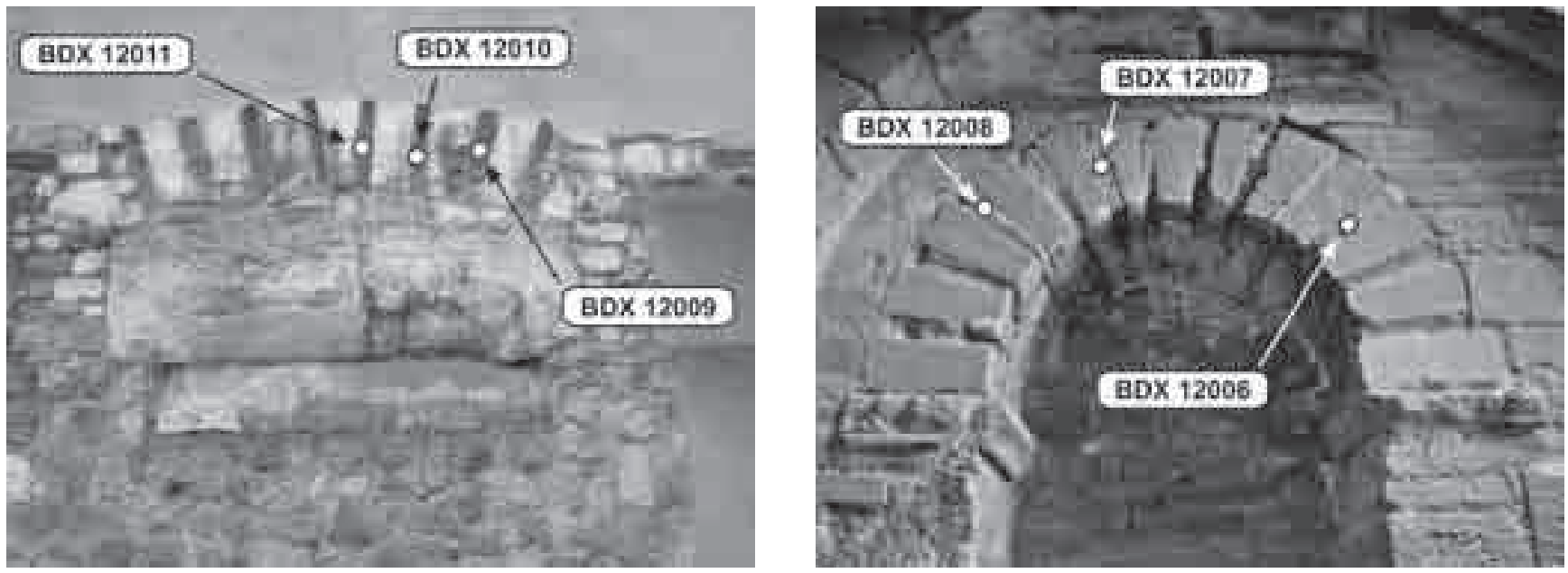

Figures 2 and 3: (See colour plate) Bricks sampled in the remaining lintel in the north surrounding wall (on the left) and in the voussoir above the south eastern window of the apse of the crypt (on the right).

Figures 2 et 3: (Voir planche couleur) Briques prélevées au-dessus du linteau préservé dans le mur nord de l'église (à gauche) et dans les claveaux au-dessus de la baie sud-est de l'abside de la crypte (à droite).

The black spots represent the sampling points/areas in bricks, made for thermoluminescence dating. Their sample codes are also indicated. Les points noirs représentent les points de prélèvement, prévus pour les datations par luminescence. Leurs références de laboratoire sont également indiquées.

\section{DATING METHODOLOGY AND ANALYTICAL RESULTS}

The methodology adopted for this study derives from well-known procedures for ceramic dating by luminescence (Aitken, 1985). The use of luminescence techniques for the dating of medieval ceramic artefacts is in fact a current practice in Europe, because of its potential and reliability (see for instance Gallo et al., 1999; Bailiff \& Holland, 2000; Galli et al., 2004; Bailiff et al., 2010; Gueli et al., 2010). The precise dating protocol used for the St Irénée bricks was designed in the Bordeaux laboratory (e.g. specifically for ceramic building material dating Guibert et al., 1998; Vieillevigne et al. 2006; Blain et al., 2007), with few changes due to the particularities of the material under study. In the case of one sample, BDX 12008, optically stimulated luminescence (OSL) was performed in addition to thermoluminescence dating (TL on coarse grains of quartz (80$200 \mu \mathrm{m})$. During this study, the evolution of techniques developed in the Bordeaux luminescence laboratory allowed us to check the suitability of OSL dating of bricks, once the method was available. Details on the preparation and techniques used are explained hereafter.

\section{Observation and preparation of the samples}

Every sample was prepared following the same process: the external part of each brick sample was mechanically removed in order to avoid surfaces exposed to the light at the time of sampling, and also to get rid of the possible external alpha and beta particles contribution (from the mortar) in annual dose rate, at the edge of the material. The powder obtained from that mechanical treatment was used for chemical composition measurements of the baked clay matrix by SEM-EDS analyses. The two ends of the cylindrical sample (some $\mathrm{mm}$ width) were used for thin sections observations and water saturation determination. A part of the core of each sample was specifically cut with a view to radionuclide concentration measurements. The final part of the core of the sample was gently crushed and prepared for luminescence dating experiments.

High resolution gamma spectrometry was used to determine the radioactivity of the bricks, which is required for the age calculation. For this purpose, a fraction of the sample was powdered by crushing, was then homogenized and then introduced into a $5,5 \mathrm{~cm}^{3}$ polythene PE container, sealed with a PVC sheet and liquid paraffin, in order to limit the escape of radon. To restore the equilibrium of uranium series due to a possible loss of radon during the preparation (notably during the drying, and powdering phases), the sample was stored for 4 weeks before measurement (more details in Guibert et al., 2009a).

For any sample, a characterization step is necessary. Thin sections of sample were observed with a petrographic 


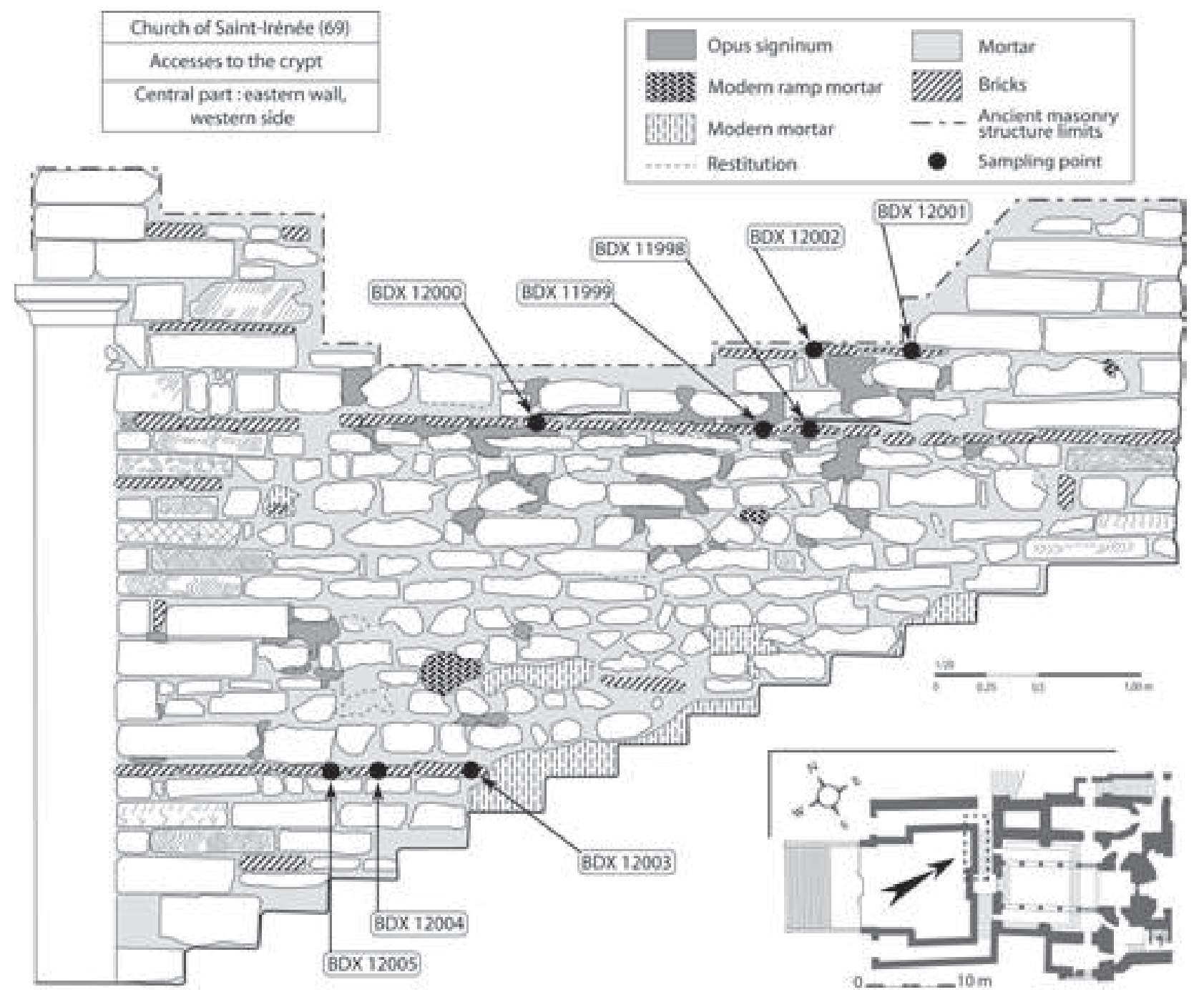

Figure 4: Northern wall of the accesses to the crypt (N. Rampnoux, M. Caillet).

Figure 4: Mur nord de l'accès à la crypte (N. Rampnoux, M. Caillet).

optical microscope. These observations provided data on the different types and sizes of inclusions within the ceramic. In addition, besides their possible use in provenance studies (this is not our concern here), petrographic analyses can help to detect the presence of highly radioactive minerals, such as zircon and monazite that could create local heterogeneities in the beta and alpha irradiation field. Furthermore, the elemental composition of each sample was determined by SEM-EDS analyses (appendix 1), in order to determine the self-absorption parameters required by the gamma spectrometry measurements to correct intensities of emerging gammas from the sample (Galloway, 1991; Guibert et al., 2009a) in comparison to the standard sample used.
The information given by the petrographic observations strongly influenced the choice of the OSL/TL protocol or technique used for dating. In this study, the technique used to date all bricks was finally that of quartz inclusion, following the steps below (Blain et al., 2007, Bouvier et al., 2011):

- Crushing and sieving (at 40, 80 and 200 micrometers); $-\mathrm{HCl}$ etching (1M or $3.7 \% \mathrm{w}$ solution) for an hour in order to dissolve carbonates, which can give spurious signals; $-\mathrm{H}_{2} \mathrm{O}_{2}$ treatment $(50 \%$ of the 110 vol. concentrated solution in distilled water) for a week in order to remove organic residues;

$-\mathrm{H}_{2} \mathrm{SiF}_{6}$ etching (weight concentration of the solution: $31 \%$ ) for a duration varying from 3 up to 5 weeks. This 
step consists in the dissolution of feldspar and other aluminosilicates. But due to differences between samples, it is necessary to check the etching with frequent cathodoluminescence control on aliquots and renew the treatment every week.

This last step is necessary to select only quartz in the sample, which HF cannot properly allow in ceramic material. Unlike sediment samples it is necessary to dissolve also the baked clay matrix and the feldspars, which is not sufficient with HF, as we experimentally observed. At the end of the preparation, there are only coarse grains of quartz left.

\section{Equivalent paleodose determination}

TL dating was performed using the multiple aliquots with added doses and signal regeneration protocol (Guibert et al., 1996). The measurements were performed with an automated TL reader designed and built at the IRAMATCRP2A (Guibert, 2002). The experimental parameters were the followings:

- heating from room temperature to $500^{\circ} \mathrm{C}$ at a rate of $4^{\circ} \mathrm{C} / \mathrm{s}$ in wet nitrogen atmosphere $\left(96 \% \mathrm{~N}_{2}, 4 \% \mathrm{H}_{2} \mathrm{O}\right.$ vapour), with a preheat at $190^{\circ} \mathrm{C}$ for two minutes;

- optical spectral window between 350 and $450 \mathrm{~nm}$ obtained from two optical filters Schott BG12 and one Schott IR rejector filter, in conjunction with the EMI 9813 QA photomultiplier tube;

- irradiations were delivered by a $90 \mathrm{Sr} / 90 \mathrm{Y} \beta$ source with a dose rate around $0.064 \mathrm{~Gy} / \mathrm{s}( \pm 1.5 \%)$ in January 2010 .

Several steps are necessary to determine the equivalent dose. The first one consists in TL measurements of the natural signal with added $\beta$ doses from 0 to 13 Gy on a first series of aliquots. The second step consists in TL measurements of regenerated signal after $\beta$ irradiations, on an annealed series of other aliquots. The $\beta$ doses given are chosen to surround those given at the first step. A non-linear function is calculated to fit the growth of regenerated TL as a function of laboratory dose. This function is then applied to natural and dose added TL signals by a slide method, which finally gives the equivalent dose (Guibert et al., 1996; Roque et al., 2004; Vieillevigne et al., 2006).

The annealing conditions between the two steps of the equivalent dose measurement are determined in order to create the same electronic state as during the brick making. This is a specific and rigorous protocol developed in Bordeaux. The regenerated TL signal is compared to the natural one after heating for one hour at different temperatures ranging from 400 to $800^{\circ} \mathrm{C}$. The chosen temperature is the one that gives the same shape of irradiation regenerated luminescence curves as the natural one (Roque et al., 2004; Vieillevigne et al., 2006).

Since the $\mathrm{H}_{2} \mathrm{SiF}_{6}$ etching does not dissolve the external part of the coarse grains of quartz, it is necessary to take into account the $\alpha$ contribution in the palaeodose determination. With this in view, a standard $\mathrm{k}$-value of $0.08 \pm 0.02$ was assumed, since the usual measurements on fine-grained material were not possible, due to the lack of material. In addition, the relatively weak contribution of the alpha particles to the total irradiation in this case did not justify measuring that parameter precisely. For quartz inclusions in these bricks, the $\mathrm{k}$ is lower than reported by Aitken (1985) but it was chosen identical to that measured on quartz from brick samples previously studied (Blain et al., 2007, 2010; Bouvier, 2011). We also observed that fact in other studies. Furthermore, quartz has an alpha effectiveness for TL irradiation lower than feldspars or fine grains of pottery.

OSL dating was performed using a classic SAR protocol (Wintle \& Murray, 2006) on automated equipment Daybreak 2200. The stimulation was done with green diodes $\left(29.6 \mathrm{~mW} . \mathrm{cm}^{-2}\right)$ and luminescence recording with an EMI 9235QB photomultiplier (detection range: 200-400 nm). The optical filter used is Hoya U340. Irradiations were performed with a ${ }^{90} \mathrm{Sr} /{ }^{90} \mathrm{Y}$ calibrated source $(0.095 \pm 0.002 \mathrm{~Gy} / \mathrm{s}$ in January 2010).

\section{Annual dose determination}

The different components of the annual dose are determined according to two different methods. Gamma and cosmic dose-rates were determined by in situ dosimetry. The TL dosimeters used are $\mathrm{CaSO}_{4}: \mathrm{Tm}$ set in brass tubes, left for around one year in drilling holes.

The $\alpha$ and $\beta$ contributions to the annual dose were determined using a high-resolution $\gamma$ spectrometer (CanberraEurisys Mesures EGPC 200 P17). U, Th and K contents were converted into $\alpha$ and $\beta$ dose rates by application of Guérin et al. (2011) conversion factors. In many cases, radioactive disequilibria are observed in the U-series. So, to evaluate the state of equilibrium, we use to measure three distinct values for $U$ content:

- the head of $U$ series, called $U\left({ }^{238} U\right)$, concerns the content of $\mathrm{U}$ deduced from the ${ }^{235} \mathrm{U},{ }^{234} \mathrm{Th}$ and ${ }^{234 \mathrm{~m}} \mathrm{~Pa}$ isotopes emissions;

- the intermediate part of $\mathrm{U}$ series, called $\mathrm{U}\left({ }^{226} \mathrm{Ra}\right)$, is the effective content in $\mathrm{U}$ measured from the ${ }^{214} \mathrm{~Pb}$ and ${ }^{214} \mathrm{Bi}$ emissions within the laboratory conditions of equilibrium between ${ }^{222} \mathrm{Rn}$ and ${ }^{226} \mathrm{Ra}$;

- the end of series, called $U\left({ }^{210} \mathrm{~Pb}\right)$, is the effective content of $\mathrm{U}$ measured from the ${ }^{210} \mathrm{~Pb}$ gamma line. 


\begin{tabular}{|c|c|c|c|c|}
\hline $\begin{array}{c}\text { Measured radioelement } \\
\text { and concentration unit }\end{array}$ & $\begin{array}{c}\text { Alpha } \\
\text { dose rate }\end{array}$ & $\begin{array}{c}\text { Beta } \\
\text { dose rate }\end{array}$ & $\begin{array}{c}\text { Gamma } \\
\text { dose rate }\end{array}$ & $\begin{array}{c}\text { Set of isotopes } \\
\text { considered }\end{array}$ \\
\hline $\mathrm{U}\left({ }^{238} \mathrm{U}\right) \mathrm{ppm}$ & 0,5706 & 0,0560 & 0,0017 & $\begin{array}{c}{ }^{238} \mathrm{U}->^{234} \mathrm{U} \\
\left({ }^{235} \mathrm{U}->^{231} \mathrm{Th}\right)\end{array}$ \\
\hline $\mathrm{U}\left({ }^{(226} \mathrm{Ra}\right) \mathrm{ppm}$ & 0,6961 & 0,0041 & 0,0020 & $\begin{array}{c}{ }^{230} \mathrm{Th}->^{226} \mathrm{Ra} \\
\left({ }^{231} \mathrm{~Pa}->{ }^{207} \mathrm{~Pb}\right)\end{array}$ \\
\hline $\mathrm{U}\left({ }^{210} \mathrm{~Pb}\right) \mathrm{ppm}$ & 1,5283 & 0,0855 & 0,1079 & ${ }^{222} \mathrm{Rn}->^{206} \mathrm{~Pb}$ \\
\hline $\mathrm{Th} \mathrm{ppm}$ & 0,7375 & 0,0277 & 0,0479 & ${ }^{232} \mathrm{Th}->{ }^{208} \mathrm{~Pb}$ \\
\hline $\mathrm{K} \%$ & & 0,7982 & 0,2491 & ${ }^{40} \mathrm{~K}->^{40} \mathrm{Ar},{ }^{40} \mathrm{Ca}$ \\
\hline
\end{tabular}

Table 2: Specific annual dose (expressed in $\mathrm{mGy} / \mathrm{a}$ ) per concentration unit deduced from recent updated values (Guérin et al., 2011) and group of isotopes considered (all nuclides of a same group are in equilibrium).

Tableau 2: Doses spécifiques annuelles (exprimées en mGy/a) par unité de concentration déduites de valeurs récemment mises à jour (Guérin et al., 2011) et groupes d'isotopes considérés (au sein d'un même groupe tous les radioéléments sont supposés en équilibre séculaire).

${ }^{210} \mathrm{~Pb}$ is used to evaluate the mean activity of radon $\left({ }^{222} \mathrm{Rn}\right)$ for the last decades, since its half-life is 22 years (the mean age of the ${ }^{210} \mathrm{~Pb}$ atoms is 32 years). Provided the sampling were recent, $\mathrm{U}\left({ }^{210} \mathrm{~Pb}\right)$ is thus used to determine the radon and daughter contribution to the annual dose in samples under their archaeological situation. The table 2 recalls or reports the annual dose factors for $\mathrm{K}, \mathrm{U}$ and $\mathrm{Th}$, and more precisely, those for the $\mathrm{U}$-series are separated respectively to the type of disequilibrium encountered and the list of isotopes involved.

\section{EXPERIMENTAL RESULTS}

\section{Sample radiochemical composition}

Table 3 reports the $\mathrm{K}, \mathrm{U}$ and Th content of samples. Among the samples, potassium, uranium and thorium concentrations show an important variability (1.72 to $3.02 \%$ for $\mathrm{K}$, from 2.80 to 10.18 for $\mathrm{U}\left({ }^{238} \mathrm{U}\right)$ and from 13 to $20 \mathrm{ppm}$ for Th). Nevertheless, two groups may be distinguished, given their $\mathrm{U}\left({ }^{226} \mathrm{Ra}\right)$ content: one group of samples with a content above $5 \mathrm{ppm}$ which exhibits a close correlation with Th, and a sort of cluster with contents in $U$ lower than 4.5 ppm (fig. 5). This variability in radiochemical composition of bricks could denote a non-uniform origin of the clay material for brick making.

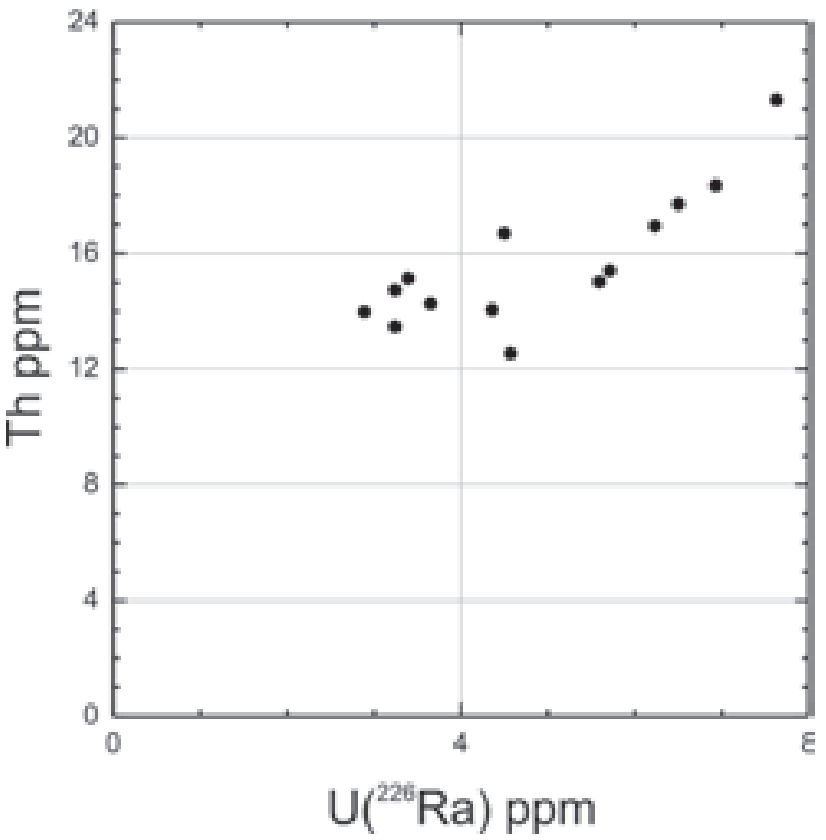

Figure 5: $\mathrm{U}\left({ }^{226} \mathrm{Ra}\right)$ - Th diagram. Figure 5: Rapport $U\left({ }^{26} R a\right)-T h$.

There is a gap between the points below $4.5 \mathrm{ppm}$ of $\mathrm{U}\left({ }^{226} \mathrm{Ra}\right)$ and above $5 \mathrm{ppm}$, which seems to constitute two groups of radio chemical composition.

Il y a un écart significatif entre les échantillons présentant une teneur inférieure à $4.5 \mathrm{ppm}$ en $U\left({ }^{26} \mathrm{Ra}\right)$ et supérieure à $5 \mathrm{ppm}$, ce qui semble constituer deux groupes de composition radiochimique distincts. 


\begin{tabular}{|c|c|c|c|c|c|c|c|}
\hline Sample code & $\% \mathrm{~K}$ & $\begin{array}{c}\mathrm{U}\left({ }^{238} \mathrm{U}\right) \\
\mathrm{ppm}\end{array}$ & $\begin{array}{c}\mathrm{U}\left({ }^{(226} \mathrm{Ra}\right) \\
\mathrm{ppm}\end{array}$ & $\begin{array}{c}\mathrm{U}\left({ }^{210} \mathrm{~Pb}\right) \\
\mathrm{ppm}\end{array}$ & $\begin{array}{c}\text { Th } \\
\text { ppm }\end{array}$ & $\mathrm{H}_{2} \mathrm{O}$ sat. $(\%)$ & $\mathrm{H}_{2} \mathrm{O}$ arc. $(\%)$ \\
\hline \multicolumn{8}{|c|}{ Accesses to the crypt } \\
\hline 11998 & $2.67 \pm 0.04$ & $3.80 \pm 0.24$ & $3.39 \pm 0.05$ & $3.34 \pm 0.32$ & $15.14 \pm 0.19$ & 4 & $2 \pm 1$ \\
\hline 11999 & $1.99 \pm 0.03$ & $3.34 \pm 0.15$ & $3.24 \pm 0.03$ & $3.12 \pm 0.23$ & $14.74 \pm 0.13$ & 3 & $2 \pm 1$ \\
\hline 12000 & $2.55 \pm 0.04$ & $4.68 \pm 0.25$ & $4.50 \pm 0.06$ & $4.58 \pm 0.40$ & $16.70 \pm 0.20$ & 4 & $2 \pm 1$ \\
\hline 12001 & $1.72 \pm 0.03$ & $3.05 \pm 0.21$ & $4.57 \pm 0.06$ & $4.93 \pm 0.38$ & $12.54 \pm 0.16$ & 4 & $2 \pm 1$ \\
\hline 12002 & $2.73 \pm 0.04$ & $2.80 \pm 0.22$ & $2.89 \pm 0.05$ & $3.00 \pm 0.37$ & $13.99 \pm 0.18$ & 4 & $2 \pm 1$ \\
\hline 12003 & $2.84 \pm 0.04$ & $7.68 \pm 0.027$ & $5.71 \pm 0.06$ & $5.41 \pm 0.40$ & $15.40 \pm 0.18$ & 4 & $2 \pm 1$ \\
\hline 12004 & $3.02 \pm 0.04$ & $6.22 \pm 0.023$ & $6.23 \pm 0.06$ & $6.05 \pm 0.38$ & $16.95 \pm 0.17$ & 3 & $2 \pm 1$ \\
\hline 12005 & $2.65 \pm 0.03$ & $9.81 \pm 0.26$ & $6.50 \pm 0.06$ & $5.84 \pm 0.32$ & $17.70 \pm 0.16$ & 4 & $3 \pm 1$ \\
\hline \multicolumn{8}{|c|}{ South-eastern window } \\
\hline 12006 & $1.88 \pm 0.03$ & $2.94 \pm 0.15$ & $3.24 \pm 0.03$ & $2.82 \pm 0.22$ & $13.46 \pm 0.13$ & 20 & $10 \pm 3$ \\
\hline 12007 & $2.29 \pm 0.03$ & $3.57 \pm 0.16$ & $3.65 \pm 0.04$ & $3.11 \pm 0.25$ & $14.26 \pm 0.14$ & 18 & $9 \pm 3$ \\
\hline 12008 & $2.96 \pm 0.04$ & $7.70 \pm 0.25$ & $7.63 \pm 0.06$ & $6.84 \pm 0.36$ & $21.31 \pm 0.19$ & 11 & $5 \pm 2$ \\
\hline \multicolumn{8}{|c|}{ Northern lintel } \\
\hline 12009 & $2.51 \pm 0.03$ & $5.75 \pm 0.19$ & $4.36 \pm 0.04$ & $4.39 \pm 0.27$ & $14.06 \pm 0.14$ & 16 & $8 \pm 3$ \\
\hline 12010 & $2.76 \pm 0.04$ & $10.18 \pm 0.27$ & $6.93 \pm 0.06$ & $6.31 \pm 0.34$ & $18.35 \pm 0.17$ & 12 & $6 \pm 4$ \\
\hline 12011 & $2.37 \pm 0.03$ & $6.79 \pm 0.20$ & $5.59 \pm 0.05$ & $5.21 \pm 0.30$ & $15.02 \pm 0.14$ & 12 & $6 \pm 4$ \\
\hline
\end{tabular}

Table 3: Radiochemical data obtained by high resolution gamma spectrometry and water content (w\%, reference dry sample).

Tableau 3: Données radiochimiques obtenues par spectrométrie gamma à bas bruit de fond.

$\mathrm{U}$ and Th contents are given in ppm, and $\mathrm{K}$ content in percent. The maximal moisture content at the saturation state and the estimated archaeological water contents are reported.

Les concentrations en $U$ et Th sont données en ppm et les concentrations en $K$ sont données en pourcent. Les pourcentages d'eau à saturation sont présentés, ainsi que les valeurs de pourcentage choisies pour le calcul des dates.

\section{Equilibrium state of the U-series}

The comparison between $\mathrm{U}\left({ }^{238} \mathrm{U}\right)$ and $\mathrm{U}\left({ }^{226} \mathrm{Ra}\right)$ gives some clues about the disequilibrium between long period isotopes. From figure 6, we can see that some of the bricks examined are in equilibrium (BDX 11998, 11999, 12000, $12002,12004,12006,12007,12008)$. On the contrary others show a well-marked disequilibrium (BDX 12001, $12003,12005,12009,12010,12011)$ with, in general, a content lower in ${ }^{226} \mathrm{Ra}$ than in ${ }^{238} \mathrm{U}$, except BDX 12001 which shows the opposite trend (table 3). This kind of distribution of $\mathrm{U}\left({ }^{238} \mathrm{U}\right) / \mathrm{Th}$ and $\mathrm{U}\left({ }^{226} \mathrm{Ra}\right) / \mathrm{Th}$ ratios for samples in disequilibrium is generally attributed to an alteration of $\mathrm{Ra}$ or $\mathrm{U}$ content. We note that the bricks which are in equilibrium correspond in a majority of cases to the low uranium content (considering $\mathrm{U}\left({ }^{226} \mathrm{Ra}\right)$ ) group of samples in comparison to the main part of samples rich in uranium. The samples of the latter type are grouped together according to a sub-horizontal line in figure 6 with a nearly constant $\mathrm{U}\left({ }^{226} \mathrm{Ra}\right) / \mathrm{Th}$ ratio. For those samples, the high variability of $U\left({ }^{238} \mathrm{U}\right) /$ Th suggests that the disequilibrium originated in a variation of the $U$ isotopes concentration, probably due to their earlier exposure to soil water as raw material. Indeed, it is really unlikely that bricks have experienced radiochemical alterations since their use in masonry, because they are in general well preserved from weathering. So this disequilibrium state may be inherited from the raw material used for the brick making. Since this disequilibrium only concerns the first long-period isotopes of the uranium series, it can be assumed that their activity had not varied significantly since the production of bricks (because the halflife of ${ }^{230} \mathrm{Th}$ is considerably greater than sample ages). We thus assume dose rate is constant. (For more details about disequilibrium of $U$ series and their consequences to luminescence dating, see Meakins et al., 1982; Murray \& Aitken, 1982; Krebtschek et al., 1994; Guibert et al., 1994, 1997; Olley et al., 1996; Kokkoris \& Liritzis, 1997; Guibert et al., 2009a.)

In general, $\mathrm{U}\left({ }^{226} \mathrm{Ra}\right)$ and $\mathrm{U}\left({ }^{210} \mathrm{~Pb}\right)$ contents are very similar in low uranium content samples (except BDX 12007) 


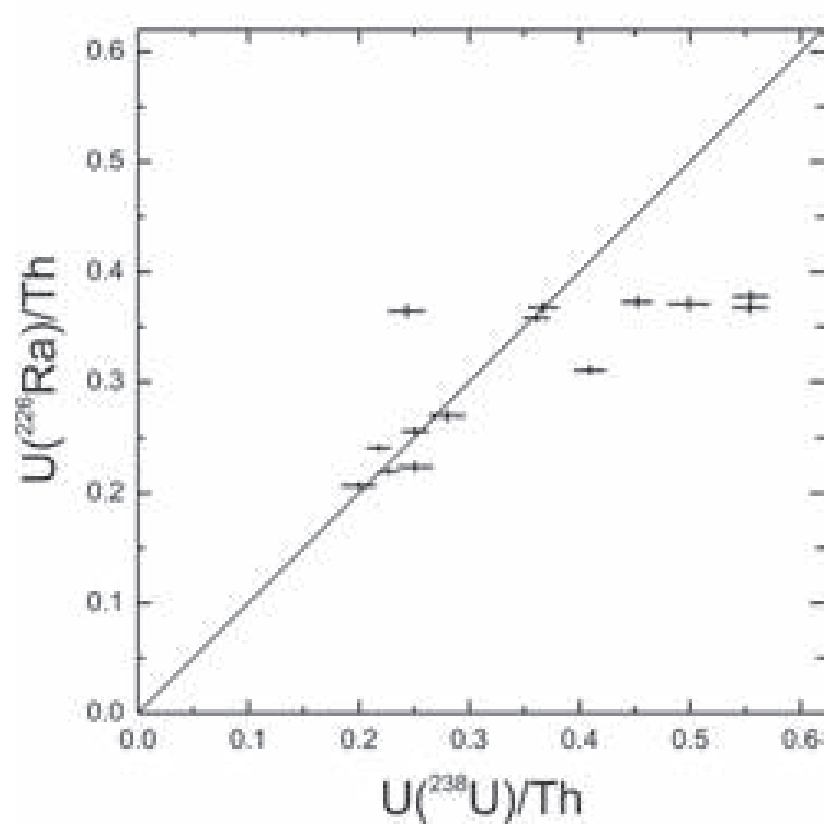

Figure 6: $\mathrm{U}\left({ }^{226} \mathrm{Ra}\right) / \mathrm{Th}$ ratio as a function of $\mathrm{U}\left({ }^{238} \mathrm{U}\right) / \mathrm{Th}$ ratio. Figure 6: $U\left({ }^{226} R a\right) / T h$ en fonction du rapport $U\left({ }^{238} U\right) / T h$. The one to one line represents the equilibrium line. Once again, the separation of samples into two main groups appears to be obvious: those in equilibrium with U/Th below 0.3 and those that are spread along a sub-horizontal line, with $\mathrm{U}\left({ }^{226} \mathrm{Ra}\right) /$ Th near 0.35. One sample (BDX 12009) has intermediate values. La première bissectrice matérialise la ligne d'équilibre. Cette fois encore, on constate la présence de deux groupes de composition assez différents : un groupe avec un rapport U/Th en dessous de 0.3 et un autre disposé en ligne subhorizontale avec un rapport $U\left({ }^{226} \mathrm{Ra}\right) / \mathrm{Th}$ voisin de 0.35. L'échantillon BDX 12009 se distingue des deux principaux groupes radiochimiques en montrant des valeurs intermédiaires.

revealing a comparable activity, even taking into account analytical uncertainties. On the contrary slight but significant differences between ${ }^{226} \mathrm{Ra}$ and ${ }^{210} \mathrm{~Pb}$ are noticeable for samples with high $\mathrm{U}$ content and of high porosity, particularly for those which also exhibit disequilibrium between $\mathrm{U}$ and $\mathrm{Ra}$ (see for instance BDX 12005, 12010 and 12011). We observe that all samples located at the exterior (except BDX 12009) are depleted in ${ }^{210} \mathrm{~Pb}$, probably this is a witness of higher rates of weathering than in the interior.

\section{Water content of brick samples}

The water content used for annual dose calculation corresponds to the estimated humidity of samples and it is assu- med that it represents an average value of water content over the archaeological times.

The saturation water content of all samples was measured and provided a maximal value for moisture content. For the accesses to the crypt (BDX 11998 to 12005), the saturation percentage was very low (between 3 and 4\%), indicating a low porosity. On the contrary, samples from the exterior of the church (northern lintel and south eastern window) showed a much higher saturation value (between 11 and $20 \%)$. We note that there is a coincidence between the outer position of the bricks and their greater porosity, but there is no apparent link, neither with their radiochemical composition nor with their disequilibrium state considering ${ }^{238} \mathrm{U}$ and ${ }^{226} \mathrm{Ra}$. However, as we already wrote a slight but significant disequilibrium between ${ }^{226} \mathrm{Ra}$ and ${ }^{210} \mathrm{~Pb}$ can be observed with the high $\mathrm{U}\left({ }^{226} \mathrm{Ra}\right)$ samples.

The further moisture percentage used in annual dose calculation depends on sample environmental context. In this study we chose to apply half saturation value with a large uncertainty to represent moisture variation since the brick making. Table 3 reports the values taken into consideration, associated with their uncertainties.

\section{Luminescence study}

Table 4 gathers luminescence data obtained or determined for each sample. Annealing temperatures of quartz varies between $500^{\circ} \mathrm{C}$ to $800^{\circ} \mathrm{C}$ according to samples, whatever the structure the bricks come from. This high extent of the annealing temperature range that is determined from the thermal behaviour of TL of quartz extracted from these archaeological bricks, seems a particularity of this site because the annealing temperature determined on grains of quartz from bricks of other medieval sites already studied by our group was in the $600-700^{\circ} \mathrm{C}$ range. The plateau region and the number of aliquots used for equivalent dose determination are presented in appendix 2 . Except in few cases, we choose to use the whole high temperature part of the TL signal $\left(250-490^{\circ} \mathrm{C}\right)$. Three of the 14 bricks sampled (BDX 12001, 12003 and 12004) could not be dated, because of insufficient sensitivity or high dispersion of TL signals. Furthermore we observed different shapes of TL curves without any correlation to age or radiochemical composition or thermal treatment. These differences seem to be independent to brick making or specificities of the raw material.

OSL measurements on sample BDX 12008 were performed using SAR protocol (Wintle \& Murray, 2006). Preheat temperature was experimentally determined and set to $200^{\circ} \mathrm{C}$ for $40 \mathrm{~s}$. In order to check the relevance of the 


\begin{tabular}{|c|c|c|c|c|c|c|}
\hline Sample code & $\begin{array}{c}\text { Equivalent } \\
\text { dose }(\mathrm{Gy})\end{array}$ & $\begin{array}{c}\text { Annealing } \\
\text { temp. }\left({ }^{\circ} \mathrm{C}\right)\end{array}$ & $\begin{array}{c}\mathrm{I}_{\alpha} \\
(\mathrm{mGy} / \mathrm{yr})\end{array}$ & $\begin{array}{c}\mathrm{I}_{\beta} \\
(\mathrm{mGy} / \mathrm{yr})\end{array}$ & $\begin{array}{c}\text { Env. } \\
\text { dose rate } \\
(\mathrm{mGy} / \mathrm{yr})\end{array}$ & $\begin{array}{c}\text { Total } \\
\text { dose rate } \\
(\mathrm{mGy} / \mathrm{yr})\end{array}$ \\
\hline 11998 & $5.05 \pm 0.28$ & 500 & $0.22 \pm 0.06$ & $2.75 \pm 0.07$ & $0.71 \pm 0.05$ & $3.67 \pm 0.12$ \\
\hline 11999 & $4.61 \pm 0.42$ & 600 & $0.21 \pm 0.05$ & $2.19 \pm 0.05$ & $1.18 \pm 0.03$ & $3.57 \pm 0.10$ \\
\hline 12000 & $6.82 \pm 0.41$ & 800 & $0.27 \pm 0.07$ & $2.83 \pm 0.07$ & $0.89 \pm 0.03$ & $3.97 \pm 0.12$ \\
\hline 12002 & $4.07 \pm 0.24$ & 650 & $0.20 \pm 0.05$ & $2.68 \pm 0.06$ & $1.14 \pm 0.03$ & $4.00 \pm 0.11$ \\
\hline 12005 & $8.34 \pm 0.61$ & 550 & $0.33 \pm 0.08$ & $3.24 \pm 0.08$ & $1.13 \pm 0.03$ & $4.68 \pm 0.14$ \\
\hline 12006 & $5.58 \pm 0.33$ & 600 & $0.18 \pm 0.05$ & $1.89 \pm 0.07$ & $0.78 \pm 0.03$ & $2.84 \pm 0.12$ \\
\hline 12007 & $7.68 \pm 0.56$ & 750 & $0.20 \pm 0.05$ & $2.26 \pm 0.08$ & $0.70 \pm 0.02$ & $3.15 \pm 0.14$ \\
\hline $12008(\mathrm{TL})$ & $6.99 \pm 0.55$ & 625 & $0.36 \pm 0.09$ & $3.45 \pm 0.10$ & $0.86 \pm 0.03$ & $4.66 \pm 0.18$ \\
\hline $12008(\mathrm{OSL})$ & $5.69 \pm 0.20$ & & & & & $1.00 \pm 0.03$ \\
\hline 12009 & $6.21 \pm 0.47$ & 650 & $0.23 \pm 0.06$ & $2.62 \pm 0.10$ & $3.84 \pm 0.16$ \\
\hline 12010 & $7.04 \pm 0.80$ & 700 & $0.34 \pm 0.09$ & $3.29 \pm 0.15$ & $1.18 \pm 0.04$ & $4.78 \pm 0.26$ \\
\hline 12011 & $5.72 \pm 0.70$ & 700 & $0.27 \pm 0.07$ & $2.70 \pm 0.12$ & $0.93 \pm 0.03$ & $3.88 \pm 0.21$ \\
\hline
\end{tabular}

Table 4: TL or OSL data and components of the annual dose: equivalent dose determined by TL or OSL measurements, annealing temperature used before regeneration in TL, alpha, beta, environmental and total dose rates. Tableau 4: Présentation des valeurs de doses équivalentes déterminées par TL et OSL, température de remise à zéro, et dose annuelle environnementale et globale.

parameters we did a recovery test, which was very satisfying (0.96). The average recuperation rate was nearly 0.02 for a bleaching illumination at $280^{\circ} \mathrm{C}$ for $40 \mathrm{~s}$.

\section{Annual dose calculation}

The annual dose has been calculated using radioelement contents measured by high resolution gamma spectrometry and converted into the dose using conversion factors published by Guérin et al. (2011), taking into account the disequilibrium in uranium series (table 3 ) and the alpha and beta particle attenuation coming from the environment of the quartz grains (table 4). We assumed also that quartz grains were not radioactive: this is based upon the result of observations of thin sections of bricks that did not show any radioactive inclusion inside coarse grains of quartz. This examination had become a routine procedure in the laboratory of Bordeaux since medieval samples from a French western site, St Philbert de Grandlieu (Dpt of LoireAtlantique) exhibited small zircon inclusions inside grains of quartz (Guibert et al., 2009b).

The transmission factors used for beta and alpha dose rates are Mejdahl's (1979) and Brennan et al.' (1991) data. Since the chemical treatments performed do not etch the external part of quartz grains, the alpha contribution to the dose has been taken into account. As explained before, a standard value of $0.08( \pm 0.02)$ was applied as $\mathrm{k}$ factor that weighted the alpha dose rate transmission factor.

A large range of grain sizes of quartz was used in TL experiments in order to get sufficient material $(80-200 \mu \mathrm{m})$. To reduce uncertainties in the mean transmission factors, supposing TL sensitivity per mass unit of material was constant whatever the grain size, the grains used for TL measurements were then sieved at 100,125 and $160 \mu \mathrm{m}$. The different fractions $(80-100,100-125,125-160,160$ $200 \mu \mathrm{m})$ were weighted and the mass proportions of any grain size class obtained were used as weighting factors of the specific attenuation factors (assuming that TL intensity is both uniform within a grain and proportional to the energy released in grains and not to the dose). Moreover, within these subclasses of grains, the grain-size distribution was taken as constant (for more details about uncertainty calculation see appendix 3).

\section{Luminescence dating of samples}

Table 5 resumes the luminescence ages and dates and corresponding standard deviations obtained for the St Irénée church bricks studied. In general, the TL measurements provide the major part of the statistical uncertainty in the ages. Besides this general comment, let us examine two apparent anomalies that can be observed with samples BDX 12007 and 12008 that come both from the arch 


\begin{tabular}{|c|c|c|c|}
\hline Masonry structure & Sample code & $\begin{array}{c}\text { Luminescence Age } \\
\text { (statistical uncertainty) }\end{array}$ & Date $68 \%$ interval $(\mathrm{AD})$ \\
\hline \multirow{3}{*}{$\begin{array}{l}\text { Accesses to the crypt, } \\
\text { middle row of bricks }\end{array}$} & BDX 11998 & $1377 \pm 89(77)$ & $\mathrm{AD}$ [543-720] \\
\hline & BDX 11999 & $1292 \pm 125(119)$ & $\mathrm{AD}[592-842]$ \\
\hline & BDX 12000 & $1717 \pm 116(104)$ & $\mathrm{AD}$ [176-407] \\
\hline $\begin{array}{l}\text { Accesses to the crypt, } \\
\text { upper row of bricks }\end{array}$ & BDX 12002 & $1018 \pm 67(60)$ & $\mathrm{AD}$ [924-1058] \\
\hline $\begin{array}{l}\text { Accesses to the crypt, } \\
\text { lower row of bricks }\end{array}$ & BDX 12005 & $1782 \pm 140(130)$ & $\mathrm{AD}[87-367]$ \\
\hline \multirow[t]{4}{*}{ South - eastern window } & BDX 12006 & $1963 \pm 139(117)$ & [93 BC-185AD] \\
\hline & BDX 12007 & $2440 \pm 201(178)$ & [631 BC-230BC] \\
\hline & \multirow{2}{*}{$\begin{array}{l}\text { BDX } 12008 \text { TL } \\
\text { BDX } 12008 \text { OSL } \\
\text { BDX } 12008 \text { moy. }\end{array}$} & $1501 \pm 128(118)$ & (TL) AD [379-636] \\
\hline & & $\begin{array}{l}1222 \pm 60(44) \\
1362 \pm 94(63)\end{array}$ & $\begin{array}{c}\text { (OSL) AD [727-847] } \\
\text { moy. AD [554-742] }\end{array}$ \\
\hline \multirow[t]{4}{*}{ Northern lintel } & BDX 12009 & $1620 \pm 139(124)$ & $\mathrm{AD}$ [251-528] \\
\hline & BDX 12010 & $1473 \pm 180(168)$ & $\mathrm{AD}[356-717]$ \\
\hline & BDX 12011 & $1473 \pm 192(181)$ & $\mathrm{AD}$ [344-728] \\
\hline & Structure mean date & & $\mathrm{AD}$ [322-559] \\
\hline
\end{tabular}

Table 5: Dates obtained for each masonry structure, total $1 \sigma$ error and statistical standard deviation given in parenthesis. All dates are expressed in years $\mathrm{AD}$, except specific indication.

Tableau 5: Présentation des dates obtenues sur chaque structure, avec la moyenne pondérée associée. Chaque date est exprimée apr. J.-C. (AD), à moins d'une mention contraire $(B C)$.

of the south east window. BDX 12007, gives a very old date, poorly precise, that shifts the apparent production date to the Iron Age. In fact, this brick is in a secondary position if we consider it had been reused from an early Roman wall. The actual environmental dose rate that is measured by dosimetry could not be representative of the mean dose-rate experienced by this material, but we do not have any possibility to correct it. The same situation is to be addressed to all samples that were recuperated from other previous buildings. Sample BDX 12008 exhibits a significant disagreement between TL and OSL measurements. As it can be seen, the complementary OSL age measurement on BDX 12008 gives a more precise age than the TL one, due to the equivalent dose determination process used, the SAR technique. However the way of uncertainty calculation may be questionned, since it is only based on dispersion of equivalent dose measurements between aliquots, and not by considering the entire OSL process (for instance, the sensitivity changes while measuring the first natural signal, by optical zeroing of anciently heated material, cannot be measured or monitored satisfactorily, although the sample passed all usual recovery, recycling and recuperation tests). We may thus consider the statistical uncertainty of the OSL age as a minimal value. Nevertheless, to integrate both informations coming from TL and OSL, we decided to calculate an arithmetic mean between TL and OSL ages of that sample that is $1362 \pm 94$ (63) a before 2009 or AD $648 \pm 94$ (63).

\section{The luminescence chronology}

Below, we present an examination of the date distribution of each masonry structure, and an overall analysis of results as well.

\section{The Northern lintel}

The dates obtained at the northern lintel form a simple case (BDX 12009, 12010, 12011). In order to check the normality of the age distribution, supposing a simultaneous production of bricks, a $\chi^{2}$ test was performed. With a 0.51 value, this one belongs to the $80 \%$ of probability range ( 0.21 to $4.61,3$ samples, 2 degrees of freedom; CEA, 1978). It shows that the dispersion is only or essentially due to statistical uncertainties. It can be assumed that the brick making for each sample was contemporary. For this masonry structure a weighted mean date of AD $441 \pm 119$ is proposed as construction date. This mean value is calculated by weighting every individual age, proportionally to 
the inverse of its statistical variance (square of the statistical standard deviation).

\section{The south-eastern window}

The bricks of the south-eastern window (BDX 12006, 12007 and 12008$)$ present widely spread dates $\left(\chi^{2}\right.$ value of 44 for a $80 \%$ range between 0.21 and 4.61, 2 degrees of freedom). The situation is opposite to that of the lintel, with a high probability of different periods of production. If the most ancient bricks are Roman, it cannot however be ascertained that all bricks were not reused. If we assume that the more recent samples characterize the date of construction of the masonry structure, the south-eastern window would have been constructed around AD $648 \pm 94$, taking into account the OSL and TL dates obtained on BDX 12008.

\section{The North-western Wall of the accesses to the crypt}

The accesses to the crypt present a more complex situation. The spread dates of these bricks (BDX 11998, 11999, 12000,12002 and 12005) again raise the question of reuse. For these five dates, three cases can be distinguished: one brick seems to be a probable Roman reuse (BDX 12005), three others, considering their uncertainties, could have been produced during the Late Roman period (BDX 11998, 11999 and 12000) and the last one (BDX 12002), during the end of the Early Middle Ages. Obviously, these dates cannot be related to the same production event $\left(\chi^{2}\right.$ value on these five dates of 50 for a $80 \%$ probability range between 1.06 and 5.39, 4 degrees of freedom). Nevertheless, it seems more consistent to associate the dates of BDX 11998, 11999 and 12000 , even if they are scattered. Otherwise, a $\chi^{2}$ test was also performed with them, in order to check their contemporaneousness. In this case, the test was not really successful, with a $\chi^{2}$ value of 6.18 between 0.21 and 4.61 at $80 \%$ ( 2 degrees of freedom) and between 0.103 and 5.99 for a $90 \%$ of probability range ( 2 degrees of freedom). We can then suppose that sample BDX 12000 is a Roman material reused.

Several chronological schemes can be drawn up, by examining the whole set of dates. The first one consists in considering that all the masonry structures were built at one time, i.e. $80 \%$ of the bricks would then be in a reuse situation and the only chronological information should be provided by BDX 12002 (10th to mid-11th century) located at the upper level of bricks of the actual stairway to the crypt.

According to a second scenario, there would be evidence for at least two periods of construction. In this case, a superposition of two building phases can be suggested, the first one being characterized by the dates obtained on BDX 11998 and 11999 (7th-8th centuries), and the second phase, by the date obtained on BDX 12002 (10th-mid 11th centuries). This hypothesis is more probable, because of the stratigraphic relationship between the different parts of the structure. If only BDX 11998 and 11999 are taken into account to date this building phase ( $\chi^{2}$ value of 0.21 between 0.016 to 2.71 at $80 \%, 1$ degree of freedom), a mean date around AD $657 \pm 78$ can be proposed. The following building phase is only dated by BDX 12002 around $991 \mathrm{AD} \pm 67$.

\section{An overall examination of luminescence dates about the production of bricks}

According to luminescence data, the existence of three main periods of brick production can be stated: Roman Antiquity, Late Roman Antiquity and end of the Early Middle Ages. The four bricks belonging to the Roman period are obviously reused here (BDX 12000, 12005, 12006 and 12007). Six samples dated to the Late Roman Antiquity (or to the very Early Middle Ages) which belong to the 4th-6th century (the three samples from the northern lintel) and to 5th-7th century intervals (BDX 11998, 11999 from the stairway to the crypt, BDX 12008 from the south-eastern window), underline at least a major building phase. And finally, one (but only one) date shows a possible building phase at the end of the Early Middle Ages (BDX 12002).

\section{Chronological interpretations}

The first stages of construction have been clarified by the results obtained, particularly by taking into account recent archaeological findings. Dates obtained on the northern lintel suggest that bricks were produced simultaneously, or within a range of dates that luminescence dating cannot discriminate (figure 7). If we accept that this production is contemporary to the building stage, it is possible to propose a chronology for the first building. Stratigraphic relationships of the masonry structures indicate a first building stage including the surrounding walls of the nave and the northern and southern openings in these walls. We recall that the weighted mean date for the northern lintel, and consequently for the first construction stage of St-Irénée's church had been done within the interval AD [322 and 559].

Additional chronological data can be matched or compared to this luminescence chronology. Firstly, the typology of construction of the walls is very similar to that of the churches of Saint-Laurent de Choulans, Saint-Pierre de Vaise and Saint-Maurice de Vienne cathedral or Notre- 
Figure 7: Distribution of dates for each masonry structure sampled (1sigma).

Figure 7: Représentation graphique de la distribution des dates pour l'ensemble des structures échantillonnées (1 sigma).

Black open circles represent reused ceramic building materials and black circles bricks produced contemporary to the construction.

Les cercles noirs et blancs correspondent aux briques gallo-romaines réutilisées et les cercles noirs aux briques produites

de manière supposée contemporaine à la construction.

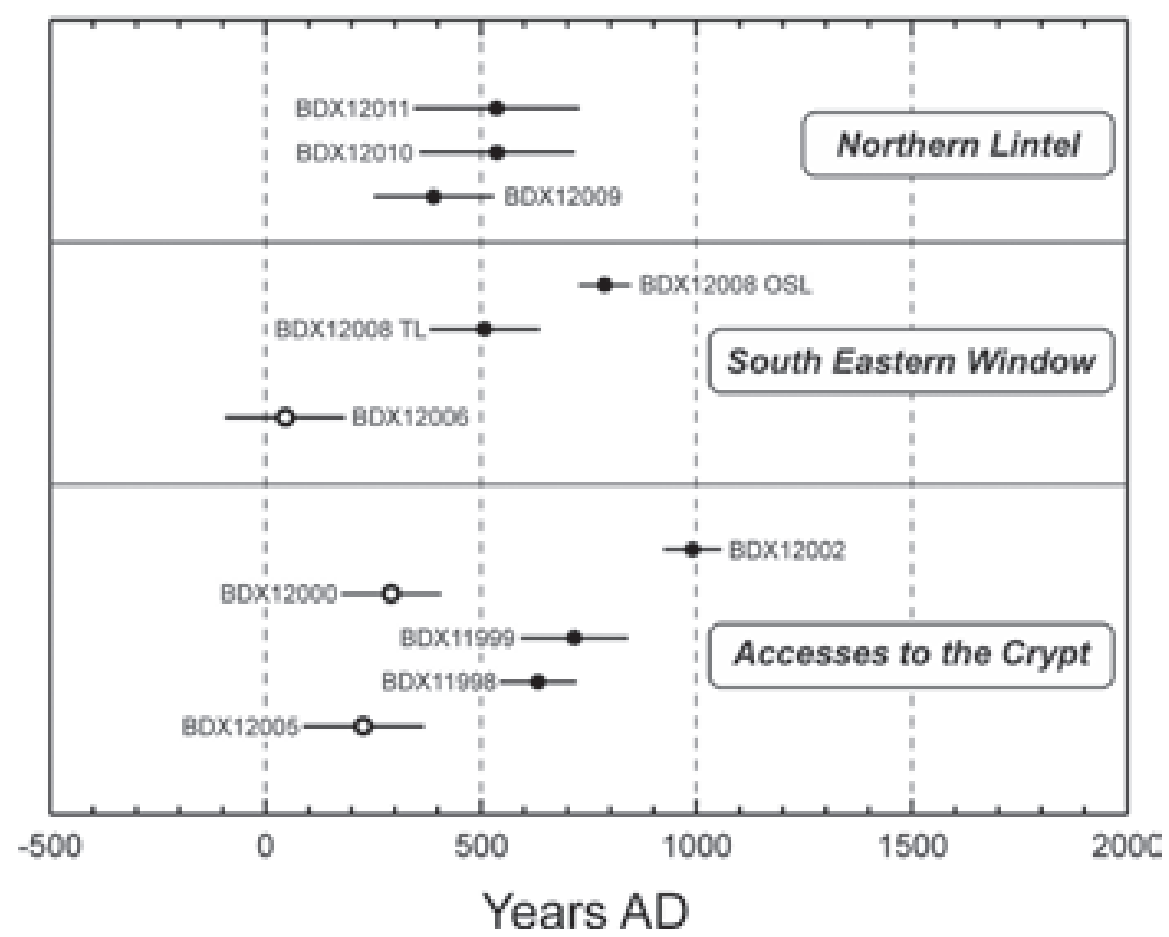

Dame d'Outre-Gère, the construction of which is attributed to a short interval, between the end of the 5th century and the beginning of the 6th century. Secondly, historians noted that between 513 and $516 \mathrm{AD}$ bishop Avitus consecrated a new church the description of which is very similar to what we know about Saint-Irénée's in the first stage. Furthermore, Saint-Irénée's is the only known church in Lyons which could correspond to this, with seven spans in the nave and a large transept (Reynaud, 1998, 2011). According to these historical data, if we suppose that Avitus really consecrated SaintIrénée's, it would provide a terminus ante quem for the first building stage, around 513-516 AD. So, the luminescence chronology and the historical approaches agree to a certain extent, and it was important for us to check the consistency between chronometry and traditional chronology.

The second building stage involves a transformation of the apse into a polygonal plan and the creation of the U-shaped accesses to the crypt. We can notice that Roman bricks were reused (BDX 12000, 12005 and 12006). Only samples BDX 11998, 11999 (accesses to the crypt) and 12008 (south eastern window) can thus characterize the second building stage or at least they were produced at the same time. We propose a building of this second stage around the end of the 6th century and the beginning of the 8th century $\mathrm{AD}$ [579-735] (at the 68\% confidence level).
According to the known history of construction, the use of rows of bricks like in Saint-Laurent of Grenoble which is assumed to have been built in the 6th-7th century (Reynaud, 1998), the Merovingian decorated stones technique like in Saint-Jean's cathedral in Lyons, suggested the same chronological period for the second building stage of St Irénée. We note again the consistency between luminescence chronology and historical considerations. If we combine both approaches, a likely chronology for the second stage of St Irénée's could be the end of the 6th century and the beginning of the 7 th century, but we must keep in mind that the contemporaneousness of St Irenee's second stage and the building of St Laurent in Grenoble and the Merovingian part of St Jean in Lyons remains hypothetical.

It is possible that one of the dates obtained gives a clue for a third building stage. It concerns the upper part of the accesses to the crypt and the transformation of the crypt into a larger space. Nonetheless, we have to be cautious in proposing a chronology with only one luminescence date characterizing this third building stage. But if we take this date into account, the third building stage could have taken place in the following interval AD [924-1058] (68\%), a chronology which is consistent with historical data and the reconstruction ordered by the bishop in the second half of the 9 th century in particular. 


\section{Conclusion}

The question of detecting reused material in medieval construction is addressed to the specialists of construction, to the archaeologists and to the material specialists as well. The results obtained at this archaeological site and at other sites also (Guibert et al., in press) highlight that the observation in situ is not always sufficient for detecting reused materials. If we can observe in some cases remains of mortar from previous masonries (e.g. Mayenne Castle, Church of Rugles in the Dpt of Eure [Blain et al., 2010]), at St-Irénée's church we did not observe any feature of that type. Our experience at St Irénée's, and at other sites studied by the GdRE, showed that an exhaustive petrographic and elementary study of the raw material cannot discriminate bricks that are contemporary to the building from reused bricks. Indeed, in the case of the study of Avranches keep (Bouvier et al., 2011), we observed an important variability in brick chemical, radiochemical and mineralogical compositions despite the fact they were produced at the same time. It is exactly the same for the samples studied from the crypt of the church of Saint-Seurin in Bordeaux, where clearly two different clays were used to make contemporary bricks (Bouvier et al., in press). The opposite case is also possible: the study of the crypt of the church of Sainte-Quitterie in Aire-sur-Adour, in the Landes department (Bouvier, 2011) showed bricks with common composition and textures, but different ages.

The observations about the reuse of older bricks raise the question of the production structures which supplied church building in the early Christian times. Furthermore, it is still difficult today to evaluate the amount of reused material in the masonry structures of the churches built during this period, unless there is specific study by means like luminescence dating methods. Nevertheless, we can notice that between the 4th and the 8th centuries, the socio-political context in Gaul was rather complex. It was an important period for church construction, but, on the other hand, the building economy is not well known from a historical point of view. To understand a practice that mixed reused and new bricks at the time of construction, we may suggest that pragmatic behaviour prevailed: when Gallo Roman monuments were present, they could have been considered as a perfect source of building materials and there was no need for the industrial organisation of production (in the sense of the quantitative importance of production). This is probably the reason why reused and new bricks can be found in the same masonry structures. New bricks would probably have been produced by a local ceramic workshop for a specific demand, even if there is currently no evidence of this. Answering these questions will be a challenge for the years to come.

\section{Acknowledgements}

Financial support: CNRS-INSHS (Institute for Human and Social Sciences), Conseil régional d'Aquitaine, DRACSRA (Regional Direction of Culture - Regional Service of Archaeology) Rhône-Alpes, Ministère de la Recherche et de l'Enseignement Supérieur, Université de Bordeaux 3, Université de Lyon 2.Scientific and technical support: Dr F.X. Le Bourdonnec, N. Rampnoux, Y. Lefrais. 
Appendix 1: Chemical composition of the samples in \%wt. Annexe 1: Composition chimique en pourcentage massique.

\begin{tabular}{|l|c|c|c|c|c|c|c|c|}
\hline & $\mathrm{Na}_{2} \mathrm{O}$ & $\mathrm{MgO}$ & $\mathrm{Al}_{2} \mathrm{O}_{3}$ & $\mathrm{SiO}_{2}$ & $\mathrm{~K}_{2} \mathrm{O}$ & $\mathrm{CaO}$ & $\mathrm{MnO}$ & $\mathrm{Fe}_{2} \mathrm{O}_{3}$ \\
\hline BDX 11998 & 1.16 & 0.96 & 19.10 & 61.03 & 5.61 & 1.04 & 0.10 & 9.85 \\
\hline BDX 11999 & 0.98 & 1.35 & 16.91 & 64.74 & 3.64 & 1.79 & 0.16 & 9.61 \\
\hline BDX 12000 & 1.13 & 1.54 & 17.79 & 57.67 & 4.57 & 5.76 & 0.13 & 10.21 \\
\hline BDX 12002 & 0.94 & 1.61 & 16.73 & 62.44 & 4.57 & 4.19 & 0.08 & 8.42 \\
\hline BDX 12003 & 1.66 & 1.81 & 17.15 & 61.01 & 4.45 & 1.80 & 0.18 & 10.74 \\
\hline BDX 12004 & 1.66 & 1.80 & 16.84 & 60.81 & 4.14 & 2.53 & 0.05 & 11.06 \\
\hline BDX 12005 & 1.35 & 2.00 & 17.39 & 60.85 & 4.11 & 3.01 & 0.21 & 10.09 \\
\hline BDX 12006 & 1.17 & 0.99 & 13.28 & 69.52 & 3.07 & 3.73 & 0.06 & 6.93 \\
\hline BDX 12007 & 1.10 & 1.44 & 17.47 & 62.62 & 3.66 & 2.28 & 0.11 & 9.48 \\
\hline BDX 12008 & 1.19 & 1.15 & 16.10 & 69.17 & 4.30 & 1.02 & 0.16 & 6.10 \\
\hline BDX 12009 & 1.66 & 1.79 & 15.47 & 68.17 & 1.45 & 0.89 & 0.05 & 7.51 \\
\hline BDX 12010 & 1.67 & 1.52 & 16.46 & 65.18 & 1.40 & 0.86 & 0.00 & 7.69 \\
\hline BDX 12011 & 1.50 & 1.62 & 15.12 & 67.67 & 1.36 & 0.85 & 0.08 & 8.34 \\
\hline
\end{tabular}

These measurements provide semi-quantitative informations whose accuracy and precision are sufficient to evaluate self absorption factors used in high resolution gamma spectrometry. $\mathrm{K}$ measurement by SEM-EDS is not used for determining efficiently the internal dose rate of ${ }^{40} \mathrm{~K}$.

Ces analyses sont présentées à titre indicatif et ne fournissent que des données semi-quantitatives. En particulier, les teneurs mesurées en $K$ au MEB-EDS ne peuvent être utilisées pour déterminer la dose annuelle de ${ }^{40} K$.

Appendix 2: Technical data for TL measurements. Annexe 2: Données analytiques utilisées pour les datations par luminescence.

\begin{tabular}{|c|c|c|c|}
\hline Sample & $\begin{array}{c}\text { Nb } \\
\text { 1st reading } \\
\text { curves }\end{array}$ & $\begin{array}{c}\text { Nb } \\
\text { 2nd reading } \\
\text { curves }\end{array}$ & Plateau values \\
\hline BDX 11998 & 20 & 19 & $255-470$ \\
\hline BDX 11999 & 17 & 14 & $255-470$ \\
\hline BDX 12000 & 17 & 18 & $255-470$ \\
\hline BDX 12002 & 20 & 20 & $255-480$ \\
\hline BDX 12005 & 18 & 20 & $255-480$ \\
\hline BDX 12006 & 16 & 14 & $290-465$ \\
\hline BDX 12007 & 12 & 11 & $295-475$ \\
\hline BDX 12008 & 18 & 19 & $255-480$ \\
\hline BDX 12009 & 18 & 20 & $335-475$ \\
\hline BDX 12010 & 15 & 17 & $255-440$ \\
\hline BDX 12011 & 14 & 17 & $255-495$ \\
\hline
\end{tabular}

Appendix 3: Calculation of uncertainty on grain size dose attenuation factors.

Annexe 3: Calcul de l'incertitude sur les facteurs d'atténuation liés à la granulométrie.

The mass distribution of grain size within two limits $\mathrm{d}_{+}$and $\mathrm{d}_{\text {- }}$ (as max and min diameter) is supposed to follow a rectangular pulse distribution. In such cases, the difference between transmission factors at the limits of the interval, $\left(f_{+}-f\right)$ is used to calculate the standard deviation of the adopted value of the transmission factor $\mathrm{f}(\mathrm{f}=(\mathrm{f}+\mathrm{f}) / 2)$ as follows: $\sigma_{\mathrm{f}}=(\mathrm{f}-\mathrm{f}) / 2 \sqrt{3}$.

La distribution massique de la granulométrie entre deux limites $d_{+}$et $d_{\text {- }}$ (diamètres maximum et minimum) est supposée suivre une distribution en créneau. La différence entre les facteurs de transmission aux limites des intervalles granulométriques $(f-f)$ est utilisée pour calculer l'écart-type sur le facteur $f$ utilisé $\left(f=\left(f_{+}+f\right) / 2\right)$. Cet écart est égal à : $\sigma_{f}=\left(f_{+}-f\right) / 2 \sqrt{3}$. 


\section{References}

Aitken M.J., 1985. Thermoluminescence dating. Academic Press, Londres, table 1.1 .

Audin A., Perrat C., 1959. Fouilles exécutées dans la crypte de Saint-Irénée de Lyon en 1956 et 1957. Bulletin Monumental, 117: 109-118.

Bailiff I., Holland N., 2000. Dating bricks of the last two millenia from Newcastle upon Tyne: a preliminary study. Radiation Measurements, 32: 615-619.

Bailiff I.K., Blain S., Graves C.P., Gurling T., Semple S., 2010. Uses and recycling of brick in medieval and Tudor English buildings: insights from the application of luminescence dating and new avenues for further research. The Archaeological Journal, 167: 165-196.

Blain S., Guibert P., Bouvier A., Vieillevigne E., Bechtel F., SAPIN C., Baylé M., 2007. TL-dating applied to building archaeology: The case of the medieval church NotreDame-Sous-Terre (Mont-Saint-Michel, France). Radiation Measurements, 42: 1483-1491.

Blain S., Bailiff I.K., Guibert P., Bouvier A., Baylé M., 2010. An intercomparison study of luminescence dating protocols and techniques applied to medieval brick samples from Normandy (France). Quaternary Geochronology, 5 (2-3): 311-316.

Bouvier A., 2011, Production et utilisation des terres cuites architecturales au début du haut Moyen Âge : apports de la chronologie par luminescence. Thèse de doctorat, université de Bordeaux 3, France: 45-64.

Bouvier A, Pinto G., Guibert P., Nicolas-Méry D., Baylé M., 2011. Luminescence dating applied to medieval architecture: the north east tower of the Avranches dungeon (Manche, France). Archéosciences, 34: 59-68.

Bouvier A., Sapin C., Guibert P., Blain S., in press. Les apports de la chronologie par luminescence : Étude de la crypte de la collégiale Saint-Seurin. Actes du colloque des $\mathrm{XX}^{\mathrm{e}}$ Journées Internationales de l'Association Française d'Archéologie Mérovingienne (4-6 octobre 2009). Aquitania, 2012.

Brennan B. J., Lyons R. G., Phillips S. W., 1991. Attenuation of alpha particle track dose for spherical grains. Radiation Measurements, 18: 249-253.

CEA, 1978. Statistique appliquée à l'exploitation des mesures. Paris, Éd. Masson.

Février P.A., Picard J. C., Pietri C., Reynaud J.F., 1986. Lyons. In Beaujard B., Février P.A., Gauthier N., Picard J.C. (dir.), Topographie chrétienne des cités de la Gaule, des origines au milieu du viiie siècle, t. 4: Province ecclésiastique de Lyons (Lugdunensis prima). Paris, Éd. De Boccard: 15-35.

Galli A., Martini M., Montanari C., Sibilia E., 2004. Datazione con termoluminescenza (TL) di strutture architettoniche della basilica di San Lorenzo Maggiore a Milano. In
La Costruzione della Basilica di San Lorenzo a Milano, L. Fieni Ed.: 219-223.

Gallo N., Fieni L., Martini M., Sibilia E., 1999. Building archaeology, ${ }^{14} \mathrm{C}$ and thermoluminescence: two examples comparison, Actes du colloque "C14 et Archéologie ». Supplément de la Revue d'Archéométrie 1999 et Mémoires de la Société de Préhistoire Française, XXVI: 425-431.

Galloway R.B., 1991. Correction for sample self-absorption in activity determination by gamma spectrometry. Nuclear Instruments and Methods in Physics Research, A300: 367-373.

Gueli A.M., Stella G., Troja S.O., Burrafato G., Fontana D., Ristuccia G.M., Zuccarello A.R., 2010. Historical buildings: luminescence dating of fine grains from bricks and mortar. Il Nuovo Cimento, 125B, 5-6: 719-729.

Guérin G., Mercier N., Adamiec G., 2011. Dose-rate conversion factors: update. Ancient TL, 29-1: 5-8.

Guibert P., 2002. Datation par luminescence des archéomatériaux : recherche méthodologiques et appliquées en archéologie médiévale et archéologie préhistorique ; progrès récents et perspectives. Habilitation à diriger des recherches, Université de Bordeaux.

Guibert P., Schvoerer M., Etcheverry M.P., Szepertyski B., Ney C., 1994. IXth millenium B.C. ceramics from Niger: detection of a U-series disequilibrium and TL dating. Quaternary Geochronology (Quaternary Science Reviews), 13: 555-561.

Guibert P., Vartanian E., Bechtel F., Schvoerer M., 1996. Non-linear approach of TL response to dose: polynomial approximation. Ancient TL, 14 (2): 7-14.

Guibert P., Bechtel F., Schvoerer M., 1997. Déséquilibre des séries de l'Uranium, implications sur la dose annuelle en datation par thermoluminescence : une étude à la Grotte XVI, Cénac et Saint-Julien, Dordogne (France). Quaternaire 8, (4): 377-389.

Guibert P., Ney C., Bechtel F., Schvoerer M., Araguas P., 1998. Datation par thermoluminescence d'éléments en terre cuite de la "Seo del Salvador ", cathédrale de Saragosse (Espagne). Revue d'Archéométrie, 23: 125-135.

Guibert P., Lahaye C., Bechtel F., 2009a. The importance of U-series disequilibrium of sediments in luminescence dating: a case study at the Roc de Marsal cave (Dordogne, France). Radiation Measurements, 44: 223-231.

Guibert P., Bailiff I. K., Blain S., Gueli A. M., Martini M., Sibilia E., Stella G., Troja S.O., 2009b. Luminescence dating of architectural ceramics from an early medieval abbey: the St-Philbert intercomparison (Loire-Atlantique, France). Radiation Measurements, 44, (5-6): 488-493.

Guibert P., Baylé M., Blain S., Bouvier A., Büttner St., Chauvin A., Dufresne Ph., Gueli A., Lanos Ph., Martini M., Prigent D., Sapin Chr., Sibilia E., Stella G., 
Troja O., 2012. The use of dating methodes for the study of building materials and constructions: state of the art and current challenges. Proceedings of the 4 th International Congress on Construction History, Paris 3-7 July 2012: 469-480.

Koкkоris M., Liritzis Y., 1997. Dose versus time for U-Disequilibrium and revised dose-rate data for TL/ESR dating. European journal of PACT 45. IV. 5: 281-294.

Krbetschek M.R., Rieser U., Zoller L., Heinicke J., 1994. Radioactive disequilibria in paleodosimetric dating of sediments. Radiation Measurements, 23 (2/3): 485-489.

Meakins R.L., Dickson B.L., Kelly J.C., 1982. The effect on thermoluminescent dating of disequilibrium in the uranium decay chain. European journal of PACT, 6: 97-103.

Mejdahl V, 1979. Thermoluminescence dating: beta-dose attenuation in quartz grains. Archaeometry, 21: 61-72.

Murray A.S., Aitken M.J., 1982. The measurement and importance of radioactive disequilibria in TL samples. European journal of PACT, 6: 155-169.

Olley J.M., Murray A., Roberts R.G., 1996. The effects of disequilibria in the uranium and thorium decay chains on burial dose rates in fluvial sediments. Quaternary Science Reviews (Quaternary Geochronology), 15: 751-760.
Reynaud J.-F., 1998. Lyon. Saint-Irénée : une basilique funéraire des V'-VII ${ }^{\mathrm{e}}$ siècles. Bulletin Monumental, 169-2: 153-155.

Reynaud J.-F., 2011. Lugdunum christianum ; Lyons du IV au VIII $^{\mathrm{e}}$ s. : topographie, nécropoles et édifices religieux. Documents d'Archéologie française, 69: 176-182.

Reynaud J.-F., Puel O., 2006. Étude archéologique de la crypte de Saint-Irénée, Rapport de fouille remis au Service régional de l'Archéologie, 42 p.

Roque C., Guibert P., Dutine M., Vartanian E., Chapoulie R., Bechtel F., 2004. Dependance of luminescence characteristics of irradiated quartz with the thermal treatment and consequences for TL dating. Geochronometria, 23: 1-8.

Vieillevigne E., Guibert P., Zuccarello A.R., Bechtel F., 2006. The potential of Optically Stimulated Luminescence for medieval building; a case study at Termez (Uzbekistan). Radiation Measurements, 41: 991-994.

Wintle A.G., Murray A.S., 2006. A review of quartz optically stimulated luminescence characteristics and their relevance in single-aliquot regeneration dating protocols. Radiation Measurements, 41(4): 369-391. 